\title{
10: 44200551-44185613
}

National Cancer Institute

\section{Source}

National Cancer Institute. 10:44200551-44185613. NCI Thesaurus. Code C42035.

Physical location of CXCL12_Gene 